\title{
Bible Interpretation, Evangelization and Faith: Nigerian Context
}

\author{
Clement I. Osunwokeh \\ Department of Philosophy and Religion, Ebonyi State University, Abakaliki, Nigeria \\ Email: clementosunwokeh@yahoo.com
}

Received 21 March 2014; revised 21 April 2014; accepted 28 April 2014

Copyright (C) 2014 by author and Scientific Research Publishing Inc.

This work is licensed under the Creative Commons Attribution International License (CC BY).

http://creativecommons.org/licenses/by/4.0/

(c) (i) Open Access

\begin{abstract}
In Christianity evangelization entails bringing the Good News of Jesus Christ into all the strata of humanity from within and making it new. Evangelization efforts in Nigeria have been going on for more than a century. Indeed it has made a noticeable inroad of growth. The evidence is seen. Thunderous sounds are heard from all corners of villages and cities, of Christian church activities; series of strategies are explored by multitude of Christian denominations aimed at "packaging and selling out" one's denomination to attract more adherents; imposing and well architectural-designed structures of Christian places of worship are seen in many cities. Yet in the same society, all forms of atrocities and abominations of man's inhumanity to man, lack of basic Christian virtues of honesty, justice, and respect for sacredness of human life are witnessed. In the light of the foregoing, this paper seeks both to presume the general shallowness of Christian faith in Nigeria and to blame it to flaw in the understanding of the Bible as a Christian text. It critically analyzes the three Christian concepts: Bible interpretation, evangelization and faith, exposing their interrelatedness and the challenges posed by such reality to an authentic Christian living.
\end{abstract}

\section{Keywords}

Christian Faith; Bible Interpretation; Evangelization; Nigeria

\section{Introduction}

The seed of Christianity sowed by the European missionaries in the African continent, Nigeria to be specific, centuries ago, can be rightly said to have grown to maturity, maturity in the sense of a huge harvest now being witnessed. These earlier missionaries no doubt inaugurated a movement of evangelization that has, thanks to the grace of God, remained unquenched. The seed of Christianity in Nigeria is indeed one in a rich soil. Its fast growth and wide spread is quite evident from the number of Christian denominations seen in every nook and 
cranny of the country.

The many Christian denominations have recently been metamorphosed into equally multiply evangelical groups popularly known as New Religious Movements. Many of their members formed themselves into crusaders and itinerant groups, "men and women who are ready to abandon even what they do for a living in order to carry the message of the gospel to the doorsteps of everyone in the society". Greater evidence of firmer implantation of Christianity in the country which no one denies, however, is the existence and ever increasing number of ordained ministers and religious men and women in the established frontline Christian denominations. If one agrees with Okoye (1984) that from the perspective of Evangelii Nuntiandi (Paul VI, 1975), evangelization is seen as a process, then the whole of the church's activity and being is evangelization. It becomes logical then to say that evangelization has made an inroad of substantial growth in Nigeria.

The scene in the contemporary Nigeria is one of general loss of qualms of conscience and utter absence of fear of God and disregard for human life and person, giving rise to general moral decadence and existence of various ills and crimes, such as injustice, bribery and corruption, stealing, armed rubbery, killing, kidnapping, rape, cultism etc. This worrisome situation calls to question the manifest inroad of growth Christianity has made in the country. It has made some like Tasie (2005) to make a comparison between the present and the "glorious past” for Nigerian society when traditional African morality reigned. Then everybody was his brother’s keeper; articles of trade displayed for sale at cross roads and by road sides were quite safe and almost everybody earned a living through legitimate means. Tasie wonders if it would be believed that the emergency of Christianity and its' consequent evangelization was what shattered "the golden era” of traditional value of justice and human dignity.

Uche (2011) sees a contradiction in the present Nigerian society which he describes as one that is so religious; so rather noisy about church, about the Christian gospel, and yet so morally deprived, witnessing daily in higher proportion, evil and crimes against justice and human dignity. The enigma created by the foregoing is one that calls for questions: could one accuse Christianity as a religion to be impotent in morality and character formation, or its Nigerian adherents for negotiation or watering down its teachings and tenets? This paper sets to address this enigma and attempts to respond to these questions.

It analyses evangelization as the essence of the church (Paul VI, 1975) which is the household of Christianity, illustrates faith as the fruit of evangelization and points to it as the cause for evangelization no impacting much on Nigerians. It projects the bible to be at the centre of both the problem and the solution, identifying biblical interpretation as the African Traditional Religion accusing the former of miscarriage of purpose and "replacing the old fear of the divinities with the relieving but harmful notion of a God who is ready to forgive perhaps even more than man is prone to sin, the God in whom goodness and severity have been put asunder” (2005: p. 90). While maintaining that the problem is not with Christianity as a religion but with the Nigerian adherents; the paper insists that exegetically correct biblical interpretation is necessary for both instilling an active Christian faith and for Christianity to be sufficiently learnt and fully comprehended by the adherents.

\section{Bible Interpretation}

Bible interpretation is a common term for many that read the bible. Many too talk about it and see it as something necessary. Christians generally believe the Bible to contain the word of God for human beings. For that reason many would agree there is need for bible interpretation. What this means is perhaps where the point of contention actually lays. Alluding to this view, Hayes, and Holladay write

Judaism and Christianity have continuously sought to understand their scriptures, to explain their contents, to appropriate their meaning, and to apply and embody their teaching. The manner in which this has been done has varied throughout history. In some respects, however, the history of Judaism and Christianity can be viewed as the history of their interpretation of the Scripture (Hayes \& Holladay, 1982: pp. 18-19).

Umoh (2007) points out that the very nature of the Bible itself further complicated the process of finding meaning in the scripture through interpretation. The Bible is not one single book, but a collection of books composed over a long period of time, by different people, under different circumstances, dealing with an extensive range of subject matter and diverse literary forms. It is not surprising therefore that the readers through the years in their search for such meaning have also approached the biblical text from different perspectives and for different purposes. Citing scholars like Schneiders (1999), he laments that within the faith community itself, there are those who believe that the Bible was written by individuals who were directly, immediate and verbally 
inspired by God, and consequently that the text is literally the Word of God whose authority is absolute and eternally binding. He sees as the other extreme, others who believe that the Bible is not different from any other ancient literature, written by human being in human language and addressing human concerns, so that any attempt to relate the Bible with divine is open to suspicion. Umoh insists, however, that the scripture is inspired, in the sense that the community of faith affirms the reality of this divine-human interaction. Even when the scriptures bear the vestiges of the human exigencies of language and other forms of limitations, they nevertheless reveal elements of the divine and can lead to the divine.

For Fuller (1981), as to how the presence of the Word of God in the Bible with a recognition of its human qualities, its error, its fallibility, cultural relativity, and the like, can be reconciled, the answer is that these human qualities belong to the earthly vessels in which the heavenly treasure is contained. He goes on to say that not only is God's Word given through human words; his sacraments show precisely the same pattern. Bread and wine, weak, beggarly elements though they are, truly convey the body and blood of Christ after a heavenly and spiritual manner to the faithful receiver. And it is the pattern of incarnation itself: in Jesus Christ that aspect of being of God which is himself going forth in self-communication became a finite human being with a limitation of a first-century Palestinian Jew.

Citing Ralph Martin, Umoh says that the primary task of the interpreter of the biblical text, is to enquire what was the meaning intended by the original authors of a text or document. He therefore thinks that it is required that his approach to the text of Scripture be honest and a determined effort to find out the intended meaning of the author for the people and communities of his day.

The Bible is the word of God for all succeeding ages. Hence, the absolute necessity of a hermeneutical theory that allows for the incorporation of the methods of literary and historical criticism within a broader model of interpretation. One branch of modern hermeneutics has stressed that human speech gains an altogether fresh status when put in writing. A written word has the capacity to be placed in new circumstances, which will illuminate it in different ways, adding new meanings to the original sense. The literal sense is from the start, open to further developments, which are produced through the "reading" of texts in new context.

Important in the issue of Bible interpretation is the fourth of four different general positions in reference to inspiration of Brown (1997). This rather intermediate position sometimes designated "centrist" does accept inspiration of scripture making God its author with the implication of inerrancy without removing human limitations. Brown says that the holders of this position maintain that the same providence of God that provided Israel's salvific history involving Moses and the prophets, endowed Christians with a basic record of salvific role and message of Jesus, is also ever supplying a Spirit that is a living aid to Christians in their ongoing interpretation.

The advocates of this fourth position of Brown's four positions in reference to biblical inspiration may well support Okure (2008) who talks of the dynamic character of God's Word; from the perspective of God and from the perspective of human beings. Okure thinks that in understanding the Bible as God's the word, word should be seen as primarily a medium of communication. What should count, therefore, is the message it communicates and the response it requires. By terminology "divine inspiration of scripture" according to Smith (1968) only denotes the special influence of God upon the human writers of the Bible, such that God is said to be the author of the biblical books.

Right from the time of the Fathers of the Church several theories of interpretation have been applied to the understanding of the Bible. Ever since the scientific revolution of the $16^{\text {th }}$ and $17^{\text {th }}$ centuries, which ushered in the modern era, it was historical criticism that has the dominant method of biblical exegesis. Side by side with their scientific method there has been also what is known as the fundamentalist approach to the interpretation of the Bible whereby a so literal sense of the Bible was defended, and it was seen as a safeguard against the literal interpretation of the Bible. Both these approaches subscribe to an objectivist, one dimensional hermeneutics, which assumes that the text of the Bible has only one true meaning, wholly independent of the cultural conditioning of the reader and the interpreter (Pathrapankal, 2002).

\section{Fundamentalist Interpretation}

In its various forms, fundamentalist interpretation accepts only a literal interpretation of the biblical text. It tends to ignore every other interpretation model that takes account of historical origin and development of the text (Umoh, 2007). Its proponents reject such conclusions about the biblical texts being approached like any other 
ancient literature without dogmatic assumptions, but with careful attention to the historical context of each constituent document. For them every statement in the Bible is accepted as revealed truth since the Bible is understood to be literally the Word of God.

Umoh points out also that the proponents of the fundamentalist interpretation insist on the five basic theological principles as the basis of every authentic interpretation. These principles include: 1) the inerrancy of scripture, 2) the historicity of the virgin birth, 3) the deity of Jesus, 4) substitutionary theory of atonement, and 5) the physical resurrection and the second coming of Jesus. Umoh thinks that even though these principles broadly speaking do not contradict basic Christian theological truth, but their application to the biblical texts sometimes leads to other issues that raise questions concerning the trustworthiness of the biblical truth. He also insists that it must be admitted however that a lot of transformation has in recent times taken place within the fundamentalists Christian groups. He further states that some scholars within the circle do not subscribe to mere naïve and simplistic approaches to the study of the Bible.

Fuller (1981) gives three reasons why Christians cannot accept the fundamentalist's position on Bible interpretation. The primary one is the Christians' own intellectual integrity that must be protected. With their Godgiven brains, the German scholars have evolved the historical method. In so far as the Bible is the product of human history, they cannot just leave their brain (their historical critical brains) outside when they come to study the Bible.

Secondly, the doctrine of verbal inspiration breaks down; too, because of the countless textual variations in the early manuscripts of the Old and New Testaments on which Christians depend for their knowledge of what the authors wrote. Which text then would be verbally inspired? Such textual complexus like the so-called textus Recceptus ("Received Text") and the so-called Johannine Comma, 1 John 5:7, both of which are not part of the original text. So Fuller says that people "are left asking, if the Bible is verbally inspired, which text is it?” (Fuller, 1981: p. 10).

Thirdly, there is historical criticism. There are contradictions of fact between the synoptic Gospels and the fourth Gospel. Jesus cleanses the temple at the end of his ministry (just before the passion) in the Synoptic and almost at the beginning of it in John.

The basic problem with fundamentalist interpretation is that, refusing to take into account historical character of biblical revelation, it makes itself incapable of accepting the full truth of the incarnation itself. As regard relationship with God, fundamentalism seeks to escape any closeness of the divine and the human. It refuses to admit that the inspired Word of God has been expressed in human language and that this word has been expressed, under divine inspiration, by human authors possessed of limited capacities and resources. For this reason, it tends to treat the biblical text as if it had been dictated word for word by the Spirit.

Furthermore, fundamentalist interpretation often historicizes material which from the start never claimed to be historical. It considers historical everything that is (told) with verbs in the past tense, failing to take the necessary account of the possibility of symbolic or figurative meaning.

Fundamentalist interpretation likewise tends to adopt very narrow point of view. It accepts the literal reality of an ancient, out-of-date cosmology simply because it is found expressed in the Bible; this blocks any dialogue with a broader way of seeing the relationship between culture and faith. Its relying upon a non-critical reading of certain texts of the Bible serves to reinforce political ideas and social attitudes that are marked by prejudices which are quite contrary to Christian Gospel. In its attachment to the principle "Scripture alone", fundamentalist interpretation separates the interpretation of the Bible from the tradition, which, guided by the Spirit, has authentically developed in union with Scripture in the heart of the community of faith. It fails to recognize that the New Testament took form within the Christian church and that it is the Holy Scripture of this church, the existence of which preceded the composition of the texts.

The fundamentalist approach is dangerous, for it is attractive to people who look to the Bible for ready answers to the problems of life. It deceives these people, offering them interpretations that are pious but illusory, instead of telling them that the Bible does not necessarily contain immediate answers to each and every problem. Without saying as much in so many words, fundamentalism actually invites people to a kind of intellectual suicide. It injects into life a false certitude; for it unwittingly confuses the divine substance of the biblical message with what are in fact its human limitations (US Conference of Catholic Bishops, 2004).

\section{Evangelization and Faith}

Evangelization and faith are two biblical concepts that go together and motivate each other. Both are vital in 
Christianity and Christian living. And both are empowered in a Christian by Jesus. Without intending to underestimate their inter-relatedness and complementarity, the paper treats them separately for better comprehension.

\section{Evangelization}

The paper defines evangelization as proclaiming and embracing the Gospel of Jesus in order to share and impact his kingdom and his salvation. In Christianity it is a task and as such it constitutes the essential mission of the church. The church exists in order to evangelize The church is an evangelizer, but she begins by being evangelized herself for her evangelization means bringing the Good News into all the strata of humanity and through its influence transforming humanity from within and making it new (Paul IV, 1975).

For Aniagwu (2001) evangelization can be understood at least in two senses. One is the sense of bringing the faith to those who have not yet embraced it. That can be called first level of evangelization. It is also, sometimes and more properly referred to as catechesis. For some Christians talk on evangelization is fundamentally about the first level. This implies that evangelization is principally the concern of ordained ministers of church and their few collaborators. The evangelization mandate issued by Jesus himself in Mathew 28: 19, however, embraces the two levels and their aspects taken as one.

For Paul IV (1975), this proclamation (kerygma, preaching or catechesis) occupies such an important place in evangelization that it has often become synonymous with it, and yet it is only one aspect of evangelization. He thinks in fact that the proclamation only reaches full development when it is listened to, accepted and assimilated, and when it arouses in the one who receives it, a genuine adherence to the truths which the Lord in his mercy has revealed.

For the Pope still, the person who has been evangelized goes on to evangelize other. Evangelization is a complex process made up of varied elements: the renewal of humanity, witness, explicit proclamation, inner adherence, entry into the community, acceptance of signs and apostolic initiative. These elements may appear to be contradictory, indeed mutually exclusive. In fact they are complementary and mutually enriching.

Agreeing with Paul IV on the real meaning of evangelization, Akukwe and Ilozumba (1990) quoting John Paul II write:

The church feels called by the Lord Jesus to an ever more intense effort on evangelization; she has special need of you, of your dynamism, you authenticity, your ardent will to grow, the freshness of your faith (1992: 5).

Okoye (1984) uses 12 verbs to describe evangelization. All the 12 verbs have Christ as their object. That Christ is the focus of evangelization is clear here. Okoye points that what evangelization brings is supremely Christ, then the Gospel/ Good News, the reign of God/Christ, faith operative in love, salvation; all of which are aspects of the same reality. The 12 verbs are: to proclaim, to announce, to bring, to promote, to preach, to spread, to advance, to share, to live, to bear witness to, to extend and to communicate. Christ is seen in his Gospel. This Gospel began when he demanded transformation and renewal of men because God's reign was near (cf. Mk.1: 15). He spent himself in bringing all under that reign. He lived the very life of God's reign. He summarized this in a series of "blessedness, pronouncement" in Mk. 5: 1-12. He held these up to society as the answer to man's quest for happiness and peace.

The complexity of evangelization as both theological and pastoral concepts has given rise to such composite terms as "new era of evangelization” Okoye (2004), “new evangelization” (John Paul II, 2000) and "reevangelization" (Buch, 1989). Okoye writes: that in anticipation of his pastoral visit to Nigeria, Pope John Paul II expressed the hope that it would initiate "a new era of evangelization". Okoye illustrates "a new era of evangelization" as 1) that which will be a fresh impulse to transform individuals and society; 2) that which will see an effective evangelization of culture such that each person in Nigeria will hear again the marvellous deeds of God in his own language (cf. Acts 2: 11) and from within his own culture; 3) that when the Gospel must now become at home; 4) that of an effective encounter between the Gospel and culture.

Addressing the $5^{\text {th }}$ Plenary Assembly of the Association of Episcopal Conference of Anglophone West Africa (AECAWA), John Buch, the Secretary General of MISSIO, has this to say:

As you well know, the Bishops of Europe and especially those in Germany discoursed the so called "reevangelization" of their people to be one of the most important tasks of their church today. And actually reevangelization seems to be one of man's challenges, if not the main challenge of our days (1989: 5).

Similarly, Ugorji (2000) thinks the great challenge of the church for years ahead is to make the local church a 
true family. He sees this to be primarily achieved by the re-evangelization of the people through a renewed proclamation of the Good News of salvation so that each member in the various parishes "deepens his/her faith, renews his/her Christian life and lives more fervently and this becomes a living witness to the Gospel” (156). The generality of Nigerian Catholic Bishops (1999) too emphasise re-evangelising lapsed Catholics whom they tagged the "lost sheep" (Lk. 15: 4-7) or the "prodigal son" (Lk. 15: 11-32). Among these are even priests and religious who have given up their vocations. The noisy and intensive evangelization activities of the 1990s were done in preparation for Evangelization 2000. The full decade long rousing and faith-provoking events that concerned the whole Christian World were seen by many Catholics as a response to Jesus' command "Go forth and make disciples of all nations"(Mt. 28: 19) and to the call of the Holy Father, Pope John Paul II to a "New Evangelization" in the church.

According to Okoye (2001), it is always to be borne in mind that the mission to evangelize the world, to make all people, to be disciples of Christ (Mt. 28: 19) is the task of the universal church. He cites Paul VI as thinking that evangelization is in fact the grace and vocation proper to the church, her deepest identity. Ugorji (2000) thinks that evolving pastoral strategies for evangelization is good. He however remarks that even the most advanced ones cannot replace the transformation action of the Holy Spirit; and recommends putting faith in the person and message of Jesus Christ accessed by both critical and spiritual reflection of God's words in the Bible, and changing ones selfish life that obstructs these.

\section{Faith}

When people talk of faith, they are inclined to relate it only to religious domain, thinking that it has nothing to do with other spheres of life. For Nwachukwu (1992), on the contrarily, people consciously or unconsciously carry out daily activities on the basis of faith. The fact is that people really believe more than they think they do. She gives an example with certain daily actions people undertake such as crossing a bridge; trusting the surface over the water on a boat; or letting the bed support them while they lie down to sleep; and thinks that this trust is not on the basis of later verification but acceptance of the persons or things in question for what they are. For Obasi (2013) too, faith exists both at the natural and religio-spiritual levels. It is the engine, the fulcrum that drives the machine of life. He therefore maintains that once we lose this faith, it will take the intervention of a significant other or even an expert to make a step in life.

Obasi further traces faith in its religious standing which he sees as a step towards reaching out to the supernatural. For him an individual needs faith in the World, faith in humanity and faith in God. From faith in its religious standing, one comes to Christian faith which gives faith as a concept its fundament. For Nwachukwu, Christian faith is not defined in terms of anyone's relation to things but

It is a personal relationship with God, which includes a knowledge of God, acceptance of his will and self abandonment in his trustworthiness. This is founded on the fact that our existence derives from him. In this relationship what is essential is that certain things about God and about what he has done are true, and as such a certain response and a certain attitude become possible and legitimate for us (Nwachukwu, 1992: p. 40).

Nwachukwu does not seem to distinguish between general faith in God and Christian faith. It may be logical to say that Christian faith is a higher faith because it is faith in God as revealed by Christ. It involves believing in Jesus Christ as the son of God and reforming ones life according to his Gospel of God's salvation. In effect Christian faith is what makes one a Christian. It is a central notion taught by Jesus Christ himself (cf. Mk. 1: 15). It is the first of the theological virtues in Christians theology. It is mostly used in reference to the Good News of Jesus Christ, man's acceptance of and sharing in this Good News, man's ultimate destiny and his life coordination to it. Christian faith has a magical power that transforms man's earthly life and creating in him a vision of heaven and of the other-world.

For Pope Francis I (2013) Christian faith is a great supernatural gift of God, brought by Jesus. It is a reality born of an encounter with the living God, which serves as a light for human beings' darkness and guiding their journey through time. He insists that faith takes on a personal aspect, and is linked to hearing. In effect, it is the Christians' response to a word which engages them personally, a participation in Jesus way of seeing things which enables them to see reality with a new eye

According to Christian theology, in an objective sense, faith is the sum of truth revealed by God in scripture and tradition which the church presents to us in brief form in its creeds. Subjectively, faith stands for the habit or virtue by which these truths are assented to. 
Barack Obama, the United States President has some interesting citations on faith. He remarks of a medical doctor who wrote to congratulate him for victory in United States Senate race,

His faith led him to strongly oppose abortion and gay marriage, but he said his faith also led him to question the idolatry of the free market and the quick resort to militarism that seemed to characterise much of President Bush's foreign policy (Obama, 2006: p. 195).

Obama makes this faith-based judgement on the doctor because he (the doctor) described himself as a Christian who understood his commitment to be comprehensive and "totalizing". For Obama, almost by definition, faith and reason operate in different domains and invite different paths to discerning truth. He also thinks that the Ten Commandments and belief in Christ's divinity are central to Christian faith.

In the understanding of Jesus, faith was an act of trust and of self-abandonment by which people no longer rely on their own strength and policies but commit themselves to the power and guiding word of him in who they believe. (cf. Mt. 21: 25, 32; Lk. 1: 20, 45). Hebrew 11: 1 defines faith "as the assurance of things hoped for, the conviction of things not seen".

\section{The Close Relationship between Bible Interpretations, Evangelization and Faith}

The unknown author of Letter to the Hebrews lists the first steps of the Christian life as "repentance from acts that lead to death, faith in God, instruction about baptisms, the laying on of hands" (6: 1-2). Obtaining these steps is summed up as salvation which for Pawson (1997) is more a horizontal line in the New Testament, a road to be travelled. He says the earliest label was not "Christianity", but "the way" (cf. Acts 16: 17; 18: 20; 19: 9, 23; 24: 14). One has to be evangelized to be able to repent from acts that estrange him from God and accepting baptism, which is life made real in faith, sustained by the Word of God that has to be interpreted to effect lifetransformation.

Faith has to be continuous, if it is to be real and to save people. One step of faith does not save one for eternity. A life of faith does. It is not the faith one starts with, it is the faith one finishes with that saves him (Pawson, 2009). For Pawson when the verb "believe" is used in the New Testament, it is used in the present continuous tense which is not easy to translate into English from Greek. The act of continuous believing made possible by the Word of God is evangelization. This Word of God, a mere medium of communication (Okure, 2008) is turned into a message to transform life by interpretation.

"Our reasons for believing must be based on facts not on 'we always did it this way"” (Hogan, 1991: p. VIII). Evangelization is aided by faith and faith is aided by Bible interpretation. The three concepts must be applied together in ensuring genuine and stable Christian life. Evangelization has to be carried on in line with Bible interpretation if it has to be sustained by faith. On another end Fuller (1981) argues,

If scripture is the Word of God insofar as it proclaimed to us Christ (was christum treibet, as Luther said) this means that is, the witness of the prophets and apostles to the Christ event, is the Word of God only within the believing community. Only there does the Word happen as Word (Fuller, 1981: pp. 16-17).

Teaching the pastors on what should constitute a basic homily Timothy Dolan says "Raw basic evangelization: primitive, fundamental kerygma; solid, faithful catechesis; solid biblical teaching-this is what our people need" (Dolan, 2000: p. 305). Dolan of course sees here evangelization, faith and Bible interpretation tied together to effect a needed life transformation that a homily is required of. Similarly Pontifical Commission for Inter-Religious Dialogue in its publication, Pro Dialogue June-December 2011, sees as mere resorting to deception and betrayal of the gospel, capable of causing harm to others, evangelization not based on the Word of God in the Bible presented as a message.

For Okogie (2001) building a church for the edification of the next and coming generations cannot of course be achieved without plan, without enthusiasm and without lasting success. He thinks here, however, that there is no better plan than to follow the plan laid down by Christ himself, built on the apostles and practised by generations after him. The greatest of the strategies Christ had for the church according to Osunwokeh (2006) is the sending down the Holy Spirit unto the church for guidance unto all truth contained in his teachings (Jn. 16: 13).

One of the major ways by which the Holy Spirit guides the church to truth and fullness of Christ's teaching is through Bible Interpretation. Egbulefu (2002) identifies a twelve fold active presence of the Holy Spirit, viewed from the perspective of Christian faith. This implies that the Holy Spirit can hardly act on a Christian without impacting faith in him. A true evangelization that has Bible correctly interpreted as its base, cannot but generate faith, as the active presence of the Holy Spirit whose fruits include faith (Gal. 5: 22). 
Bible interpretation involves an academic process and a study which inform and underpin one's experience of God in Jesus Christ (Carey, 1993), which is faith; the witness of this process in effect is evangelization. Carey believes there is need to infuse an academic process in evangelization if faith is to be authentic.

Unlike in the African Traditional Religion, where as Ikwuagwu (2007) holds, no element of formal dogma or theology as basis of faith for an adherent, Christian faith that motivates evangelization is based on God's revelation contained in the Bible. This follows that the level of individual's comprehension of the Bible determines the level of his faith. This is partly why Osunwokeh (2013) thinks that for an African Christian religion is a phenomenon one must struggle to accept. Osunwokeh argues, that although his (African Christian) Africaness makes him naturally religious (Ikwuagwu, 2007, agreeing with scholars, like Mbiti and others), his Christianity is a mixed conception of religiousity. The problem of African Christian being "in a state of dilemma when it comes to belief" (Madu, 1999: p. XV) is this. Religious comprehension that cannot be harmonized between Bible interpretation and evangelization that generate faith remains divided and devoid of sharpness, solidity and clarity.

\section{Evaluation of Close Relationship between Bible Interpretations, Evangelization and Faith}

Bible interpretation, evangelization and faith are to be seen as Christian concepts that should be tied together and regarded as vital in the appraisal of Christianity as a religion. This interrelatedness of these concepts springs basically from the fact of Christianity, like most major World religions, having the Bible as a sacred text, "where terms and themes, doctrines and theologies, dogmas and tenets are contained, alluded to, denoted and reflected" (Osunwokeh, 2009). Since this sacred text is generally regarded by the Christians as "a book of revelation", its level of comprehension determines a Christian's level of faith and his level of attainment of evangelization. The high level and degree of faith and evangelization in Paul of Tarsus, evidenced in the 22 books of the New Testament attributed to him or containing his history testifies to these. Paul's deep knowledge of Jesus' life, death, resurrection and ministry that he claims was reveal to him by Christ himself in several of his writings is the reason for these. Christian faith is not something one receives once and for all. It is a life that is lived. This is done by a continuous critical search of the Bible containing the Word of God in the Gospel of Jesus Christ. Oforkansi (1998) and a host of others would blame the early missionaries' failure to utilize the people's culture and sound traditional religious belief for the present anomalies of African Christianity not impacting much on the morality of the society and not being sufficiently relevant to the society. This paper disagrees with them and rather blames the Christians themselves for not deepening their Christian faith by a continuous search of their text containing Christian principle, laws and tenets.

Hayward talks of "the cause of the Gospel, distorted and betrayed by a religiousity and a religious institution devoid of the Scriptures and incapable of putting man in living communion with Christ” (Hayward, 1971: p. 164). Hayward's is a lamentation of evangelization cut off of its roots that receives no life and incapable of generating deep faith. Similarly, Akukwe and Ilozumba (1990) are saddened that in the midst of thunderous noise of evangelization from all corners of the country, the Nigerian youths are searching for meaning in life everywhere. What else can one adduce to be the reason why the Africans (Nigerians) known to be deeply religious and having feelings of an irresistible religious imperative cannot but have something quite positive to offer to the realm of religion, other than surface based evangelization.

\section{Conclusion}

No one can make a Christian life capable of sustaining into salvation by uneducated or uninformed faith (Hogan, 1991). Although the Holy Spirit is the illuminator, the one to whom both scholar and believer must turn, there must be a desire by everyone to search for, to learn, and to be taught the message of the Bible as the Word of God. Humility is important and sincerity is a must. All selfishness and self indulgence suppressed. Only the proclamation, projection, profession and confession of the Lord Jesus Christ and his the Good News should be the sole aim, motive and desire of an evangelizer interpreting the Word of God.

It must agreed that Christians scripture that have their roots in the writings and traditions did not drop from heaven on tablets; they were laboriously written and re-written, line by line, over the cause of thousands of years (Matins, 1975). Hence Obijiaku (2013) while seeing the much talk about inculturation and enculturation by scholars as a welcomed development for African Christianity, insists it has to be undertaken in a sound theological manner. 
While this paper may support the much talk about enculturation by scholars, it agrees with Obijiaku (2013) that it is welcome development for the African Christianity, and has to be undertaken in a sound theological manner devoid of all nationalistic or parochial sense and self identity. The motive should be to make the Good News clearer not necessarily acceptable.

When an evangelizer has ulterior motives behind his ministration of the word of the God, there cannot be a guarantee of unbiased interpretation of it. Nwabekee (2002) laments the subsequent multiplication of churches in Africa, and especially in Nigeria what he calls "miracle church". He reveals that some of those who began these churches understand the religiousity of the Africans, coupled with the poverty-stricken nature of their state, and so try to exploit the situation in order to enrich themselves materially. They use the proclamation of the Word of God for personal gain and care little about its authenticity and implication to Christian living. They memorize the Bible verses simply to impress and make no effort to find their meaning and message. The result is that both evangelizer and evangelized wallow in shallow faith that cannot reflect a Christian living.

Obama (2006) talks of inauthentic expression of faith which he thinks nothing is more transparent than. As he advocates the need for the Americans to think of "thou" not just "I" and take faith seriously not simply to block the religious right but to engage all persons of faith in the larger project of American renewal; the paper too advocates the need for the Christians to think of "thou", "Christ" not just "I" in their handling of God's Word. They must also take faith seriously not just to obtain favour from God or from men, but to engage all persons of faith in the larger project of Good News of God's Kingdom and renewal of Mankind.

\section{References}

Akukwe, F. N., \& Ilozumba, C. C. (1990). Youth and Evangelization. Enugu: Trinity Press Ltd.

Aniagwu, J. (2001). The Clergy, Religious Vocations and Evangelization in the Archdiocese of Lagos. In J. Aniagwu (Ed.), Archdiocese of Lagos, Acts and Declaration of the Second Synod: Evangelization in New Millennium. Ikeja: Jeromelaiho and Associates Ltd.

Brown, R. (1997). Introduction to the New Testament. New York: Double Day Press.

Buch, J. (1989). Association of Episcopal Conferences of Anglophone West African. Minutes of the $5^{\text {th }}$ Plenary Assembly. Kumasi: AECAWA Publication.

Carey, G. (1993). The Importance of Theology for the Charismatic Movement. In H. D. Hunter, \& P. D. Hoclan (Eds.), All Together in One Place. Sheffield: Sheffield Academic Press.

CSN (1999). Church in Nigeria: Family of God on Mission. Lagos: Sovereign Ventures.

Dolan, T. (2000). Priests for the Third Millennium. Huntington, IN: Our Sunday Visitor, INC.

Egbulefu, J. (2002). The Identity of the Holy Spirit: An Appreciation of the Person, Presence, and Action of the Holy Spirit as God the Vivified, Unifier, Justifier and Sanctifier. Encounter, A Journal of African Life and Religion, 2, 62-71.

Francis, I. (2013). Encyclical Letter Lumen Fidei to the Bishop, Priest and Deacons Consecrated Persons and the Lay Faithful on Faith. Abakaliki: Citizen Advocate Publications.

Fuller, R. H. (1981). The Use of the Bible in Preaching. Winter Park, FL: The Bible Reader.

Hayes, J. H., \& Holladay, C. R. (1982). Biblical Exegesis. London: SCM Press.

Hayward, V. (1971). Latin America-An Ecumenical Bird’s Eye View. International Review of Mission, 60, 161-185.

Hogan, F. (1991). Can You Trust The Bible? Ann Arbor, MI: Servant Publications

Ikwuagwu, A. O. (2007). Initiation in African Traditional Religion. Bamberg: Echter Verlag.

Madu, J. E. (1999). Honesty to African Cultural Heritage. Calabar: Franedo Publishers (Ng.) Ltd.

Nwabekee, A. (2002). Consolation Theology and Corruption in Africa: The Nigerian Perspective. In V. M. Okeke (Ed.), The Nature and Identity of the Church. Nigerian Theological Perspective. Enugu: Snaap Press.

Nwachukwu, M. S. (1992). Faith Confronting Suffering. The Nigerian Situation in Encounter. A Journal of Life and Religion, $1,39-43$.

Obama, B. (2006). The Audacity of Hope. New York: Three Rivers Press.

Obasi, C. I. (2013). Faith in the Year of Faith. Bigard Theological Studies. A Journal of Bigard Memorial Seminary,33, IIIVII.

Oforkansi, A. O. (1998). Culture in Ora-eri. Abeokuta: Pinnacle Graphics.

Okogie, A. (2001). Address Declaring the Synod Open. In J. Anieagwu (Eds.), Archdiocese of Lagos, Acts and Declaration of the Second Synod: Evangelization in New Millennium. Ikeja: Jeromelaiho and Associates Ltd. 
Okoye, J. I. (2001). Biblical Studies and Seminary Formation in Post-Jubilee Bigard. In V. M. Okeke (Eds.), Bigard Diamond Jubilee Essays. Nsukka: Fulladu Publishing Company.

Okoye, J. C. (1984). What Will Be New about the New Era of Evangelization? In Proceedings of the National Seminary on New Era of Evangelization. Ibadan: SS Peter and Paul Seminary.

Okure, T. (2008). Alive and Active: God's Word in Nigeria Context (Unpublished Paper). Inaugural Convention of the Catholic Biblical Association of Nigeria (CABAN) Port Harcourt.

Osunwokeh, C. I. (2006). The Holy Spirit and the $21^{\text {st }}$ Century Church. Journal of New Testament Research, 1, 92-112.

Osunwokeh, C. I. (2009). Fundamentalism/ Fanaticism: A Perfect Recipe for Crisis and Intolerance. Amamihe Journal of Applied Philosophy, 7, 89-105.

Osunwokeh, C. I. (2013). African Traditional Values of Justice and Human Dignity: A challenge to the African Christianity. Unpublished Paper.

Pathrapankal, J. (2002). True and Historical Biblical and Theological Studies. Bangalore: Asian Trading Corporation.

Paul, V. I. (1975). Apostolic Exhortation Evangelii Nuntiandi. Vatican City: Polyglot Press.

Pawson, D. (1997). Jesus Baptized in One Holy Spirit. Wiltshire: Terra Nova Publication International Ltd.

Pawson, D. (2009). Israel in the New Testament. Bradford: Terra Nova Publication International Ltd.

Smith, R. F. (1968). Inspiration and Inerrancy. In R. E. Brown et al. (Eds.), The Jerome Biblical Commentary. London: Geoffrey Chapman.

Tasie, G. I. K. (2005). Religion and Moral Depravity in Contemporary Nigeria. Nigerian Journal of Theology, 19 , 88-98.

Uche, C. (2011). The Witness of Life: A Challenge to the Catholic Priesthood in the 21st Century. In J. O. Oguejiofor, \& A. C. Oburota (Eds.), Challenges of Priest in the Century. Enugu: Bigard Press.

Umoh, C. (2007). The Influence of the New Christian Movements on Bible Interpretation in the Nigerian Church. In A. G. Nnamani (Ed.), The New Religious Movement: Pentecostalism in Perspective. Benin City: Ava Publisher. 